\title{
Chapter 1 \\ Wetlands and Water Framework \\ Directive: Protection, Management and Climate Change
}

\section{S. Ignar and M. Grygoruk}

\begin{abstract}
In this chapter the general context of protection and management of wetlands in legal frameworks of water management is discussed. We present the background of the book, referring to its main conclusions and achievements. The main finding is that the existing regulations of the European environmental policy are sufficiently accurate and provide adequate tools to maintain good status of ecosystems as well as to restore the degraded ecosystems that provide a potential of reaching the favourable environmental status. However, implementation of these regulations requires attention and enhancement, as in selected cases it fails to fulfil their environmental objectives. We state that the main attention of the EU environmental policy the day before, when the good status of waters and aquatic ecosystems demanded by the water framework directive has to be met by the member states, should pay special attention at assessment of the implementation efficiency of existing legal regulations rather than at the development of the new ones. We conclude that in order to succeed with the adaptive management of wetlands facing climate change, social sciences should be more deeply involved in EU environmental policy inducing attitudes of managing authorities and users of valuable wetlands.
\end{abstract}

Keywords Wetlands - Water framework directive - Climate change • Environment $\cdot$ Conservation

\footnotetext{
S. Ignar · M. Grygoruk (西)

Department of Hydraulic Engineering, Warsaw University of Life Sciences - SGGW, ul. Nowoursynowska 159, 02-776 Warsaw, Poland

e-mail: m.grygoruk@levis.sggw.pl

(C) The Author(s) 2015

S. Ignar and M. Grygoruk (eds.), Wetlands and Water Framework Directive,

GeoPlanet: Earth and Planetary Sciences, DOI 10.1007/978-3-319-13764-3_1
} 


\subsection{Status of Wetlands: Missing Law or Failed Implementation?}

In a contemporary world the number of environmental directives, laws and conventions allows one to suspect that the surrounding nature is protected better than any time before in the history and the only issue one can expect in environmental management is the increasing quality (or at least retaining a constant good ecological state) of Earth's ecosystems. Particularly in the case of valuable wetlands, there is a considerable number of legal agents allowing conservationists to look bravely towards the future. Starting from the international Ramsar convention on wetlands, through the European council directive 92/43/EEC on the conservation of natural habitats and of wild fauna and flora [referred to as the habitats directive (HD)], council directive 2009/147/EC on the conservation of wild birds [referred to as the birds directive (BD)] and directive 2000/60/EC of the European parliament and of the council of 23 October 2000 establishing a framework for community action in the field of water policy [the water framework directive (WFD)], ending at national and regional regulations (water acts, environmental conservation acts and regional authority's resolutions). However, a day-to-day experience in environmental conservation does not allow optimistic attitudes to dominate the practitioner's world: ecosystems, in general, deteriorate globally. On top of humanenforced pressures originating from contamination of waters, agriculture, forestry, landscape fragmentation and urbanization (Hassan et al. 2005), the new threats to ecosystems such as the ones related to the changing climate (Rannow et al. 2014) have been defined. These threats are vitally critical for wetlands - transitional ecosystems shaped by the physical and biological process typical for both terrestrial and aquatic environments. One could expect that in face of new challenges that wetlands are exposed to, the revision of legal frameworks regulating management and use of these ecosystems should be done and-perhaps - new directives should be developed. Beforehand, however, concerning the abundance of legal tools, one should verify whether the general threats for waters and wetlands do not raise from an improper implementation of existing, in a way much comprehensive, legal regulations concerning the environment. Then, answering the question "do regulations miss accuracy or does the implementation fail?" one can start the discussion on how to enhance the protection and management of wetlands, facing new challenges such as the human- and climate-related pressures.

\subsection{Wetlands and Water Framework Directive}

As stated by Joosten and Clarke (2002), among the continents the most significant loss of water-dependent ecosystems in the global scale was recorded in Europe, where the areal decline of wetlands reached over $50 \%$ of their pristine extent. They also state that pressures originating from agriculture and forestry are responsible for 
approximately $80 \%$ of these cases. Among the greatest challenges wetlands faced so far and are up to be exposed to in the near future, the drainage and declining water levels are considered as the most critical ones. As revealed, projected climatic changes expressed as increasing temporal and quantitative variability of extreme meteorological events are expected to significantly influence agriculture and forestry by challenging field works, species development and harvesting of crops gained from wetlands (Grygoruk et al. 2014). Changing environmental conditions of wetlands are projected either to require in-depth adaptation of existing management or to develop new approaches. It is likely that changing frequencies of floods and droughts, observed trends in snow accumulation and variability in the occurrence of seasons will primarily affect economic development, which will require actions to be undertaken in order to prevent negative influences of these changes to stakeholders. Then, the pressures oriented at water management, in Central Europe in principal oriented at mitigation of frequent floods, may result (and already do) in degradation of aquatic ecosystems (Biereżnoj-Bazille and Grygoruk 2013; Dembek 2015; Mioduszewski and Okruszko 2012). Pressures originating from agriculture on revitalization of land reclamation systems and training rivers in order to assure the continuous retrieval and transfer of water downstream have already induced conflicts between the need of implementation of WFD and social requirements (Dembek 2015). Although in national context it seems the win-win situations are achieved and contemporary measures undertaken at river management level (dredging, ditch revitalization) fulfil all the requirements of WFD, HD, BD and environmental impact assessments (EIA), the deeper detailed insights into such activities revealed that to meet the good ecological status of rivers and water bodies appears - sadly - the last thing to be achieved by 2015 (Biereżnoj-Bazille and Grygoruk 2013; Strużyński et al. 2015).

Examples from Poland and Germany presented in this book allow to foresee coming benefits for the environment originating from WFD implementation. However, the same examples allow to suspect that the future of WFD implementation without providing appropriate funding background, either by adjustment of national governmental mechanisms or EU-scale programmes aimed at subsidizing the implementing bodies, does not appear bright (Grygoruk and Okruszko 2015). In the current perspective and facing actions undertaken so far expressing WFD implementation, it is likely that on top of the biotic and hydrochemical aspects of water bodies, the hydromorphology and quantitative indicators of river status are ones whose connection to status of wetlands will be the strongest. Regardless of hydrological types of wetlands, from mires, through floodplains to estuaries, one should assure consideration of wetlands as inherent elements of river continua and include them in a catchment-scale environmental management. 


\subsection{Protection and Management}

Although the considerable potential for synergies between the regulations regarding water resource management (WFD) and nature conservation (HD and BD) does exist, it is not fully exploited yet (Stratmann and Albrecht 2015). The concept of ecosystem services of wetlands may allow to sustain their high ecological quality by putting environmental features in economic terms, thus enhancing social perception of conservation of these ecosystems (Grygoruk et al. 2013; Maltby 2009). The links between wetlands acting as inherent elements of catchments improving quality of aquatic geosystems should, however, be revisited in WFD implementation (Meyerhoff and Dehnhardt 2007). Dembek (2015), making a step from environmental research towards social sciences, convinces that the management of agriculturally maintained wetlands requires more holistic approach, where the anthropocentric anticipation of use of wetlands should switch to attitudes concerning protection of wetlands as principal goal in wetland management. Bearing in mind that to conserve wetlands does not mean to lose them in economic perspective, we see that the integration of economic and environmental scopes of wetland management, especially interfered by the climate change, may be achieved in modern management of aquatic and riparian ecosystems. As stated by Strużyński et al. (2015), it is vital to continue river restoration in order to assure matter and energy transfer between rivers and floodplain wetlands. Despite the fact that increasing concern in river management is put to the catchment processes, still the great field to be explored is an interrelation of catchment-scale water management and habitat conservation (Grygoruk et al. 2013; Janauer et al. 2015).

\subsection{Climate Change}

WFD, despite of being a universal approach to water bodies conservation and management, does not comprehensively consider climate change as an aspect that might influence achievements of its goals to rivers or wetlands (Wilby et al. 2006). Such a status should be revisited, as projected climate-change-induced pressures to habitats reported in both European (Okruszko et al. 2011; Schneider et al. 2011) and regional context (Doroftei and Anastasiu 2014; Grygoruk et al. 2014; Kaligaric and Ivajnšic 2014; Malatinszky et al. 2014), together with actions undertaken by stakeholders mitigating climate change influences are foreseen to play a very important role in protected areas management in the near future. As reported by Grygoruk et al. (2014), not only direct pressures originating from the changing climate (such as global warming, flooding, droughts) challenge wetlands by affecting water balance and habitat conditions. Equally (if not more) relevant for wetland ecosystem status are actions undertaken by stakeholders allowing them to continue the use of wetlands, mitigating negative effects of the climate-related impacts. In a capitalistic world the only way of changing attitudes of stakeholders to 
management measures in order to keep the use of wetlands in an environmental sustainable, yet profitable manner, is to build their capacity towards consideration of climatic change as a local-scale issue. Numerous scientific and management projects implemented throughout the Europe, such as the HABIT-CHANGE project, attempted to enhance stakeholder dialogue between the environmental management institutions and particular groups of people, whose actions determine the use and status of valuable ecosystems. Changing of stakeholder's attitudes was done either by broadening their knowledge on climate-related impacts on habitats and management or by inducing their emotions stating that the climatic change is unavoidable and the lack of adaptation will result in further deterioration of ecosystems, wetlands especially, and reduction of income from activities done regardless of the variable impacts of climate.

However, the majority of national-level adaptation strategies lack connection to local actions (Rannow et al. 2014) and hence the management of valuable wetlands requires stronger insights coming from international climate-adaptation policy towards the single plots located on valuable wetlands.

\subsection{Yesterday's Lessons and Tomorrow's Perspectives}

Facing considerable abundance of regulations (that have been attempted to be) implemented in the geographical, societal, environmental and economic perspectives of Europe in the last 20 years, it seems that European union does not require any new directives concerning the interface of wetlands, water management and climatic change to be developed. Moreover, observing steadily increasing awareness of stakeholders regarding requirements and costs of implementation of existing environmental regulations, we doubt that any new regulations inducing obstacles for users of water and goods that origin from the natural wetland environment can be socially accepted and then developed and implemented in the near future. On the other hand, it is widely agreed in groups of practitioners and scientists from Europe that existing regulations, such as the WFD, $\mathrm{HD}$ and $\mathrm{BD}$, contain sufficiently good regulations that, once efficiently implemented, may prevent degradation of wetlands and water bodies, assure sustainable water management in social and economic context as well as allow to mitigate climate-related primary and secondary pressures to ecosystems and catchments (Janauer et al. 2015). We hope the lessons presented in this book will allow readers to conclude which fields of management of wetlands facing their status in WFD and concerning prospective pressures originating in the changing climate require special attention. We also hope that the enhancement of efficiency in implementation of the existing environmental regulations in EU in the near future will assure good status of waters and wetlands as properly managed ecosystems, resilient to impacts originating from human pressures and climatic change. 
Open Access This chapter is distributed under the terms of the Creative Commons Attribution Noncommercial License, which permits any noncommercial use, distribution, and reproduction in any medium, provided the original author(s) and source are credited.

\section{References}

Biereżnoj-Bazille U, Grygoruk M (2013) Scale matters: efficiency assessment of EU environmental directives implementation in a local-scale management of protected wetlands in Poland. Sci Ann Danube Delta Inst 19:5-12

Dembek W (2015) New vision of the role of land reclamation systems in nature protection and water management. In: Ignar S, Grygoruk M (eds) Wetlands and water framerwok directive: protection, management and climate change, GeoPlanet: Earth and planetary sciences. Springer, Berlin

Doroftei M, Anastasiu P (2014) Potential impacts of climate change on habitats and their effects on invasive plant species in Danube delta biosphere reserve, Romania. In: Rannow S, Neubert M (eds) Managing protected areas in central and eastern europe under climate change, advances in global change research 58. Springer, Berlin

Grygoruk M, Okruszko T (2015) Do water management and climate-adapted management of wetlands interfere in practice? Lessons from the Biebrza Valley, Poland. In: Ignar S, Grygoruk M (eds) Wetlands and water framework directive: protection, management and climate change, GeoPlanet: Earth and planetary sciences. Springer, Berlin

Grygoruk M, Mirosław-Świątek D, Chrzanowska W, Ignar S (2013) How much for water? Economic assessment and mapping of floodplain water storage as a catchment-scale ecosystem service of wetlands. Water 5:1760-1778

Grygoruk M, Biereżnoj-Bazille U, Mazgajski M, Sienkiewicz J (2014) Climate-induced challenges for wetlands: revealing the background for the adaptive ecosystem management in the Biebrza Valley, Poland. In: Rannow S, Neubert M (eds) Managing protected areas in central and eastern europe under climate change, advances in global change research 58. Springer, Berlin

Hassan R, Scholes R, Ash N (2005) Ecosystems and human well-being: current state and trends, millenium ecosystem assessment, vol 1. Islandpress, Washington DC

Janauer GA, Albrecht J, Stratmann L (2015) Synergies and conflicts between water framework directive and natura 2000: legal requirements, technical guidance and experiences from practice. In: Ignar S, Grygoruk M (eds) Wetlands and water framework directive: protection, management and climate change, GeoPlanet: Earth and planetary sciences. Springer, Berlin

Joosten H, Clarke D (2002) Wise use of mires and peatlands-background and principles including a framework for decision making. Int Mire Conserv Group Int Peat Soc 304:204

Kaligaric M, Ivajnšic D (2014) Habitat changes caused by sea level rise, driven by climate change in the northern Adriatic coastal wetlands, Slovenia. In: Rannow S, Neubert M (eds) Managing protected areas in central and eastern Europe under climate change, advances in global change research 58. Springer, Berlin

Malatinszky Á, Ádam S, Falusi E, Saláta D, Penksza K (2014) Suggested management measures for Natura 2000 habitats in Körös-Maros National Park, Hungary. In: Rannow S, Neubert M (eds) Managing protected areas in central and eastern Europe under climate change, advances in global change research 58. Springer, Berlin

Maltby E (2009) Functional assessment of wetlands: towards evaluation of ecosystem services. Woodhead Publishing Ltd., Cambridge, p 672

Meyerhoff J, Dehnhardt A (2007) The European water framework directive and economic valuation of wetlands: the restoration of floodplains along the river Elbe. Environ Policy Governance 17:18-36

Mioduszewski W, Okruszko T (2012) Protection of natural wetlands - the examples of conflicts. J Water Land Dev 16:35-42 
Okruszko T, Duel H, Acreman M, Grygoruk M, Flörke M, Schneider C (2011) Broad scale ecosystem services of European wetlands - overview of the current situation and future perspectives under different climate and water management scenarios. Hydrol Sci J 53:15011517

Rannow S, Neubert M, Stratmann L (2014) Natural heritage at risk by climate change. In: Rannow S, Neubert M (eds) Managing protected areas in central and eastern Europe under climate change, advances in global change research 58. Springer, Berlin

Schneider C, Flörke M, Geerling G, Duel H, Grygoruk M, Okruszko T (2011) The future of European floodplain wetlands under a changing climate. J Water Clim Change 2:106-122

Stratmann L, Albrecht J (2015) Can natura 2000 sites benefit from river basin management planning under a changing climate? Lessons from Germany. In: Ignar S, Grygoruk M (eds) Wetlands and water framework directive: protection, management and climate change, GeoPlanet: Earth and planetary sciences. Springer, Berlin

Strużyński A, Książek L, Bartnik W, Radecki-Pawlik A, Plesiński K, Florek J, Wyrębek M, Strutyński M (2015) Wetlands in river valleys as an effect of fluvial processes and anthropopression. In: Ignar S, Grygoruk M (eds) Wetlands and water framework directive: protection, management and climate change, GeoPlanet: Earth and planetary sciences. Springer, Berlin

Wilby RL, Orr HG, Hedger M, Forrow D, Blackmore M (2006) Risks posed by climate change to the delivery of water framework directive objectives in the UK. Environ Int 32:1043-1055 